\title{
Examining Distinctive Indicator Scopes Measuring Well-Being in Sustainable Development Assessment
}

\author{
Takehiro Hatakeyama ${ }^{1}$ \\ 1 Institute of Sustainability Governance, Faculty of Sustainability, Leuphana University of Lüneburg, \\ Universitätsallee 1, D-21335 Lüneburg, Germany \\ Correspondence: Takehiro Hatakeyama, Institute of Sustainability Governance, Faculty of Sustainability, \\ Leuphana University of Lüneburg, Universitätsallee 1, D-21335 Lüneburg, Germany. E-mail: \\ takehiro.hatakeyama@stud.leuphana.de
}

Received: March 15, 2021

doi:10.5539/jsd.v14n3p58

\author{
Accepted: April 7, $2021 \quad$ Online Published: April 9, 2021
}

URL: https://doi.org/10.5539/jsd.v14n3p58

\begin{abstract}
The significance of acknowledging well-being (WB) has increased in local sustainable development (SD) assessment. Meanwhile, scholars and practitioners have paid growing attention to using subjective indicators which rely on a person's subjective evaluation to measure SD subjects, due to the frequent critique. The predominant use of objective indicators to assess SD frequently overlooks capturing individual's and community's WB. Nevertheless, the scopes and functions of subjective indicators remain underexamined in the SD assessment context. Therefore, this study discusses the distinctive characteristics of subjective sustainable development indicators (SDIs), contrasting with objective SDIs, complemented by examining WB indicators. To this end, an analysis of the literature on indicator-based assessment of SD and WB at the community and local level was conducted. The findings highlighted that the three distinctive approaches of SDIs could optimally capture and address associated WB: the objective SDIs could most sufficiently capture and address material WB capture, which turned, however, the shortcoming that overlooks other dimensions of WB. In contrast, the expert-led subjective SDIs could optimally capture and address community's social WB, whereby the outcomes reflected social norms and preferences recognised by a community and sustainability theories. Likewise, the citizen-based subjective SDIs distinctly measured individual's life satisfaction levels, whereby the outcomes explicitly presented individual's subjective WB while addressing local needs and values. This study finally suggests that the complementary use of the respective SDIs contributes to a thorough local-level SD assessment, by optimally addressing associated WB, which ultimately helps meet the current and future generations' WB in achieving local SD.
\end{abstract}

Keywords: indicator-based assessment, social well-being, subjective indicators, subjective well-being, sustainable development indicators

\section{Introduction}

Using appropriate indicators in assessing sustainable development (SD) at the local level has been recognised as important by practitioners and scholars across disciplines. The concept of SD includes considerable practical wisdom and 'normative choice about what we value and how much we value it (Beemsterboer \& Kemp, 2016).'

The first explicit encouragement regarding practicing assessment of SD at the local level was articulated in Local Agenda 21, adopted by the United Nations (UNs) World Conference on the Environment and Development in 1992. Following that, the UNs initiative, the Sustainable Development Goals (SDGs) adopted in 2015, has emphasised using adequate indicators to measure the SD progress at all levels to facilitate evidence-based decisionmaking while articulating meeting WB (Allen et al., 2017). Indicator-based assessment is one of the most broadly used approaches to SD assessment in academic research and practices (Hezri \& Dovers 2006; Munda, 2013). However, the predominant use of indicators primarily relying on objective measurements in assessing SD has attracted critiques from scholars and practitioners; for instance, using Gross Domestic Product (GDP) to measure SD progress often overlook capturing factors that influence on citizen's WB, due to its narrow economic scope and neglecting subjective assessment (Stiglitz, Sen, \& Fitoussi, 2009). Accordingly, several alternative indicators have been developed to overcome the shortcoming; although often for international- or national-level assessments. For instance, the Index of Sustainable Economic Welfare calculates the cost of environmental degradation and 
defense expenditure in addition to economic growth figure, although it does not consider social WB or human health unless they affect economic factors (Villamagna \& Giesecke, 2014). Likewise, the Genuine Progress Indicator calculates the costs of the negative effects of economic activities and social costs overlooked by GDP, such as unpaid household labour (D'Acci, 2011; Sirgy, 2011). Yet, the scopes of these alternatives rely largely on objective measures, thus cannot fill 'a gap between what could be measured and what occurred in a society (Stiglitz et al., 2009).

Given that indicators, relying on objective measurements are inaccurate to capture the subjective dimensions of SD, which are often intertwined with WB (Fasolo Galetto, \& Turina, 2013; Jordan et al., 2010), indicators relying on subjective measurements (i.e., subjective indicators) play a crucial role. Prior to the analysis, this study distinguishes objective and subjective indicators from quantitative and qualitative indicators. Eurostat (2014) suggests that quantitative and qualitative indicators can be defined, focusing on 'how' to measure subjects and collect and present data, whereas objective and subjective indicators refer to 'what' is measured, considering the objective and subjective nature. Although objective and subjective indicators can measure both types of subjects, the information delivered explicitly reflect the characteristics of respective indicators ; for instance, criminal rate (objective) and people's fear of crime (subjective). Given that this study's focus is on examining WB. which is understood as measurement subjects, the term objective and subjective indicators is referred to.

While subjective indicators have been well examined in the WB study (e.g., Bleys, 2012; D'Acci,2011), studies examining their scopes and functions in SD assessment are scarce (e.g., Craheix et al., 2015; Singh, Murty, Gupta, \& Dikshit, 2012). Accordingly, this study specifies varying approaches of sustainable development indicators (SDIs) and discusses the distinctive scopes and functions of subjective SDIs (i.e., expert-led and citizen-based) and objective SDIs, complemented by identifying and examining the characteristics of differentiated WB and the related indicators. To this end, analysis on the literature of indicator-based assessment of SD and WB is conducted. Here, this study poses the following research questions: 'What is the conceptual limitation of using objective indicators in assessing SD, and what roles and functions do subjective SDIs instead play?'; 'What does the incorporation of measuring WB in SDIs influence on local-level SD assessment?' As a reminder of the paper, Section 2 introduces this study's method. Section 3 elaborates the concepts of SD, WB, and basic human needs as the overarching subjects to be measured by indicators, while discussing the theoretical grounding of the major scopes of the overall SDIs. Section 4 examines major indicators employed in state-of-the-art practices of SD and WB assessment to explore the extent to which the conceptual and theoretical findings are identified and further specifies the respective SDIs scopes. Finally, Section 5 discusses the distinctive scopes and functions of the objective and subjective SDIs while providing the overview and implications for further study and practice.

\section{Materials and Method}

This study conducted the literature search, using the Web of Science database, considering that the size and breadth of its scientific citation index identify a reliably diverse and unbiased selection of articles, journals, and publishers (Cohen, 2017). The initial starting point was 2001 when sustainability science was broadly accepted as an academic discipline (Barrington-Leigh \& Escande, 2016; Cohen, 2017) and WB began increasingly recognised (Barrington-Leigh \& Escande, 2016) by scholars. To elicit the most relevant articles, it used the following search terms within the categories of 'environmental studies' and 'environmental sciences':

'(qualitative indicators OR human well-being) AND sustainability' \& '(indicators AND indices) AND (human well-being OR sustainability)'

Seeing that the search terms 'sustainable development' and 'subjective indicators' provided fewer results than 'sustainability' and 'qualitative indicators', the latter terms were chosen for the literature search. Additionally, i this study established the following eligibility criteria to ensure the article's relevance to the analysis: 1) The articles studying indicator-based SD assessments at the local and community level, which discussed the concept of SD and indicator scopes; and employed a set of indicators incorporating either or both objective and subjective indicators. 2) The articles studying indicator-based assessment of WB at the local or community level, which discussed the concept of WB in relation to SD and indicator scopes; and employed a set of indicators incorporating either or both objective and subjective indicators. 3) The articles were peer-reviewed, written in English, and available in either an open-access or a hybrid journal. Based on the criteria, it scanned the titles and abstracts of the numerous articles, resulting from the first search $(n=3,045)$ to produce an initial body of papers $(n=236)$. Further, screening of full texts was conducted, whereby the following studies were excluded: those aimed to develop methodologies of indicator measurements, re-calculated existing indicator variables, and employed only one specific type of indicators (e.g., environmental indicators). Consequently, the final number of eligible articles was derived $(\mathrm{n}=85)$ (see Figure 1). 
Regarding the indicator-based assessment of SDGs, several studies obtained from the literature search discuss how existing indicator systems can adequately measure and monitor SDG targets and goals, and how they (partially) contribute to the achievement (e.g., Doyle \& Perez-Alaniz, 2017; Mayer, Haas, \& Wiedenhofer, 2017; Schaubroeck \& Rugani, 2017). However, none of those articles examine the SDG indicator system per se, thus the discussion is out of this study's scope.

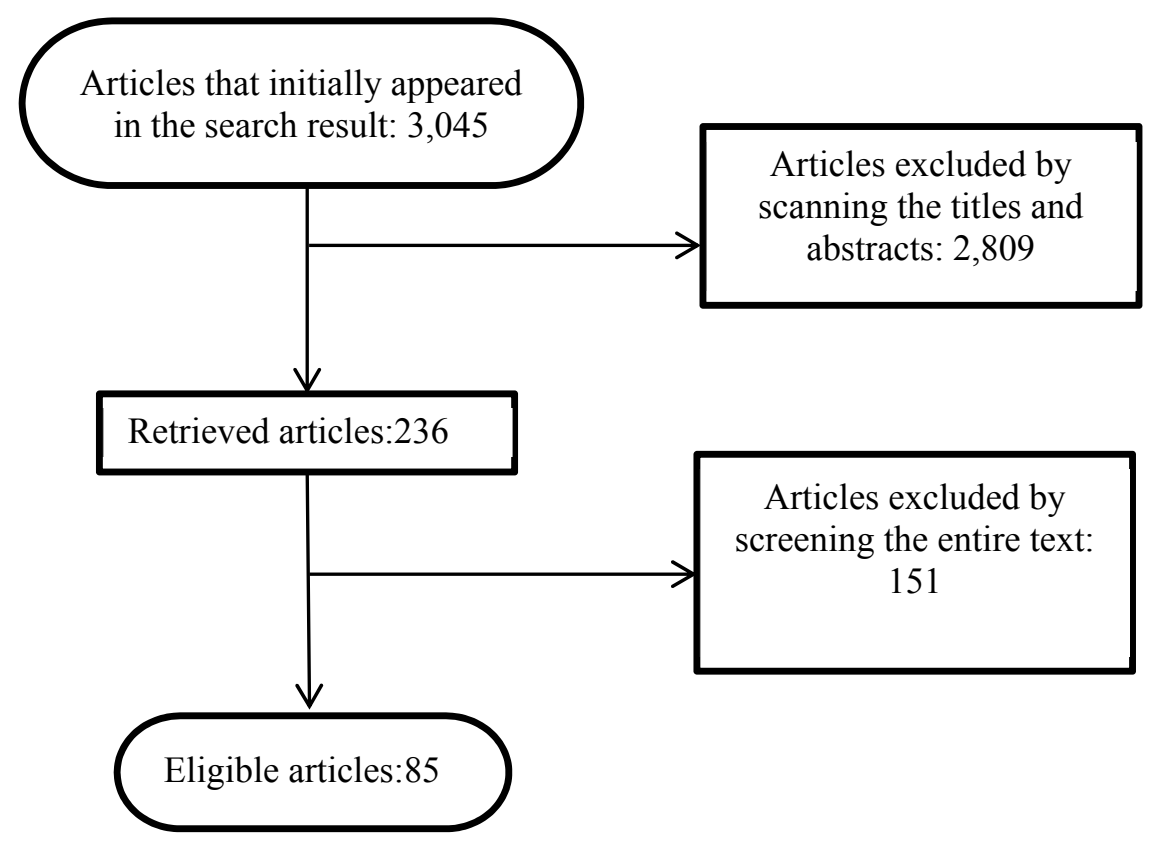

Figure 1. A flowchart representing the literature selection process

\section{Conceptual and Theoretical Findings: Conceptual and Theoretical Understanding of Sustainable Development Indicators}

\subsection{Theoretical Background and Different Scopes of Sustainable Development Indicators}

Table1 presents the most common theoretical backgrounds for SDIs. Developing SDIs begins with raw data, which are non-valuated values, derived from a survey, and these values convert into a single indicator with a specific purpose. Further, single indicators are either grouped to form composite indicators or synthesised to create aggregate indicators or an index, which can be further gathered to form indices; index and indices entail the most elaborated information system, thus the most holistic measurement perspective (de Jonge et al., 2012; Latruffe et al., 2016). Meanwhile, the practicability and the reliability of SDIs must be validated by eligible criteria. Although the SMART principle -specific, measurable, attainable, realistic, and time-related- is widely referred to as a fundamental standard to ensure the practicability and reliability of SDIs, various studies suggest other essential criteria, such as policy relevance, data availability, ease of interpretation, analytical soundness, sensitivity to stress, and representativeness of objectives (Blancas, Lozano-Oyola, González, Guerrero, \& Caballero, 2011; GallegoÁlvarez et al., 2015; Haider et al., 2018; Li, Zhang, Yuan, Liu, \& Fan, 2012; Wei, Zhao, Xu, \& Yu, 2007; Zhen \& Routray, 2003). 
Table1. An overview of the theoretical grounding for the development of sustainable development indicators

\begin{tabular}{|c|c|c|c|c|}
\hline \multicolumn{5}{|c|}{ Theoretical Grounding of Sustainable Development Indicators } \\
\hline & \multicolumn{4}{|c|}{ Raw data } \\
\hline & \multicolumn{4}{|c|}{$\downarrow$} \\
\hline Construction & \multicolumn{4}{|c|}{ Indicator (scientifically converted) } \\
\hline \multirow[t]{3}{*}{ Order } & \multicolumn{2}{|c|}{$\downarrow$ (grouped) } & \multicolumn{2}{|c|}{$\downarrow$ (synthesized) } \\
\hline & \multirow{2}{*}{\multicolumn{2}{|c|}{ Composite Indicators }} & \multirow{2}{*}{\multicolumn{2}{|c|}{$\begin{array}{l}\text { Aggregate Indicators } \\
\text { Index/Indices }\end{array}$}} \\
\hline & & & & \\
\hline \multirow{6}{*}{ Selection Criteria } & & Specific & \multirow{6}{*}{$\begin{array}{c}\text { Other essential } \\
\text { criteria }\end{array}$} & Policy relevance \\
\hline & & Measurable & & Understandability \\
\hline & SMART & Attainable & & Data availability \\
\hline & criteria & Realistic & & Analytical soundness \\
\hline & & Time-related & & Stress sensitive \\
\hline & & & & Representativity \\
\hline
\end{tabular}

The findings also highlight the two major s which the overall SDIs employ in the measurements (see Table 2). First, pillar-based scaling - also known as the Triple Bottom Line (Alfaro-Navarro et al., 2017; Sureeyatanapas, Yang, \& Bamford, 2015) - defines the measurement categories based on the three pillars of SD, to which measurement subjects are determined and indicators are developed, while some may add other pillars, such as an institutional pillar (e.g., Antwi et al., 2017; Haider et al., 2018; Schneider et al., 2015). The examples of the scaling are seen in the existing indicator systems. The Ecological Footprint measures environmental subjects by calculating ecological productivity for a given population, including resource production and pollutant absorption (Phillis, Grigoroudis, \& Kouikoglou, 2011). Economic measurements primarily assess subjects, such as economic inequity (e.g., unemployment rate), income distribution, public debt, and stock and flow of goods and services (King et al., 2014; Strezov, Evans, \& Evans, 2017); an example is the Sustainable Society Index, which collectively calculates economic variables (c.f., Gallego-Álvarez et al., 2015). Finally, the set of composite indicators to monitor national SD performances, developed by the United Nations Commission for Sustainable Development measures subjects in the social pillar, such as equality, conditions of health, education, housing, and population (Singh et al., 2012). Given that SDIs generally integrate variables in different pillars, equal weighting of which facilitates the tangible analysis of SD impacts on different systems and feasible measurements of the intricacies of SD (Bleys, 2012; Estoque \& Murayama, 2014), although its shortfall is to oversimplify the complexity of the goals (Cohen, 2017). Second, spatiotemporal scaling helps identify and measure trade-offs occurring within and across spatiotemporal boundaries in the SD process (Adams, Pressey, \& Stoeckl, 2014; Kammerbauer et al., 2001). Spatial scaling defines a geographical or jurisdictive boundary, within and across which measurements can be made. It ensures the relevance of SDIs to the context and an appropriate understanding of its condition (Blancas et al., 2011; de Jonge et al., 2012), thus enables the measurements to capture context-specific (basic) needs, which influence on intra-generational equity upon meeting a certain level (Reig-Martínez, 2013; Wang et al., 2018). Meanwhile, temporal scaling allows for evaluating the past development and predicting the future achievement of long-term SD; assessing time relationship is particularly crucial when it comes to capturing socioeconomic changes over time while maximising current and future WB, which can enhance the inter-generational equity (Kaklauskas et al., 2018; Morse, Vogiatzakis, \& Griffiths, 2011; Ottaviani, 2018; Villamagna \& Giesecke, 2014). However, insufficient incorporation of this scaling in indicator systems jeopardises the data reliability and usability of SDIs (Koop \& van Leeuwen 2015).

Furthermore, a single SDI relies on either objective or subjective measurements based on different valuation methods and thus produces contrasting (outcome) data (see Table 2) (Bhuiyan, Siwar, \& Ismail, 2016; Fasolo et al., 2013; Ottaviani, 2018; Peano, Tecco, Dansero, Girgenti, \& Sottile, 2015; Singh et al., 2012). Objective SDIs gauge physical conditions of dynamic systems by quantifying the complexities; and are incorporated in numerous frameworks measuring SD (e.g., the indicators for Planetary Boundaries) and most SD goals, including SDGs which involve a large number of quantifiable targets (Doyle \&Perez-Alaniz, 2017; O'Neill, 2012; Singh et al., 
2012). Valuation of objective SDIs refers to available statistic data or variables from existing quantitative models, and the data derived from this method can reflect normative values -or scales - which represent pre-defined science or policy references (Blancas et al., 2011; Craheix et al., 2015; Herrera, Gerster-Bentaya, \& Knierim, 2016; Ottaviani, 2018). This is particularly effective for measuring inputs and flows and outputs within a given system (e.g., a condition of material wealth). However, objective SDIs may be subject to data restriction in the case that publicly available data are sparse (Koop \& van Leeuwen 2015). Hence, an alternative approach to overcome the flaw is needed.

Meanwhile, subjective SDIs support a systematic understanding of the environment and society through measuring subjects that reflect the subjectivity, ambiguity, and context-dependency of SD (Craheix et al., 2015; Reed, Fraser, \& Dougill, 2006; Singh et al., 2012). Valuations of subjective SDIs are identified two-fold. First, an exogenous approach utilises expert opinion and knowledge as a reliable source of scientific and technical information for (qualitatively) weighting variables. (Craheix et al., 2015; Talukder, Hipel, \& van Loon, 2017). It facilitates communication among stakeholders, fosters in-depth knowledge exchange, and promotes interactive learning across domains, incorporating empirical and interpretative perspectives (Schneider et al., 2015). Accordingly, it helps detect which SD fields are most important for the present and future visions based on the social preferences regarding SD revealed to the given context (Gómez-Limón \& Sanchez-Fernandez, 2010; Schneider et al., 2015), although the selection of experts often leads to bias which considers merely specific aspects of SD (Craheix et al., 2015; Pinar, Cruciani, Giove, \& Sostero, 2014). Studies also suggest that the outcome data derived from this method can ground on either normative or relative values - or importance - which is assigned when there are either no standard (referenceable) values are available or subjective information are needed (Craheix et al., 2015; Ottaviani, 2018). Second, personal evaluation incorporating self-perception utilises individuals' attitudes, levels of satisfaction, and behavioural intentions for weighting variables (Choi \& Sirakaya, 2005; Diener \& Sue, 1997; Moser, 2009), and the outcome data derived from this method ground on relative values. It enables optimal measurements of substantially intangible subjects, such as quality of life or life satisfaction (e.g., Bleys, 2012; King et al., 2014). Additionally, direct inputs from local individuals mirror local concerns and knowledge of the local system, which enhances the local relevance of SDIs (Graymore, 2014). However, gathering the valuation source (e.g., individuals) often faces temporal and geographical constraints, which thus diminishes the spatiotemporal availability and reliability of the data (Craheix et al., 2015; Kammerbauer et al., 2001). The findings also imply that the subjective SDIs identified can be particularly suitable to a community- and local-level SD assessment, assuming that referring to relative values can address subjective values based on the local realities (e.g., individuals' life satisfaction and community's social preference) in assessment outcomes, while referring to normative values helps associate global SD issues (e.g., $\mathrm{CO} 2$ emission amount as a contributor of the climate change) with local practices.

Table 2. An overview of the major scopes common to overall sustainable development indicators

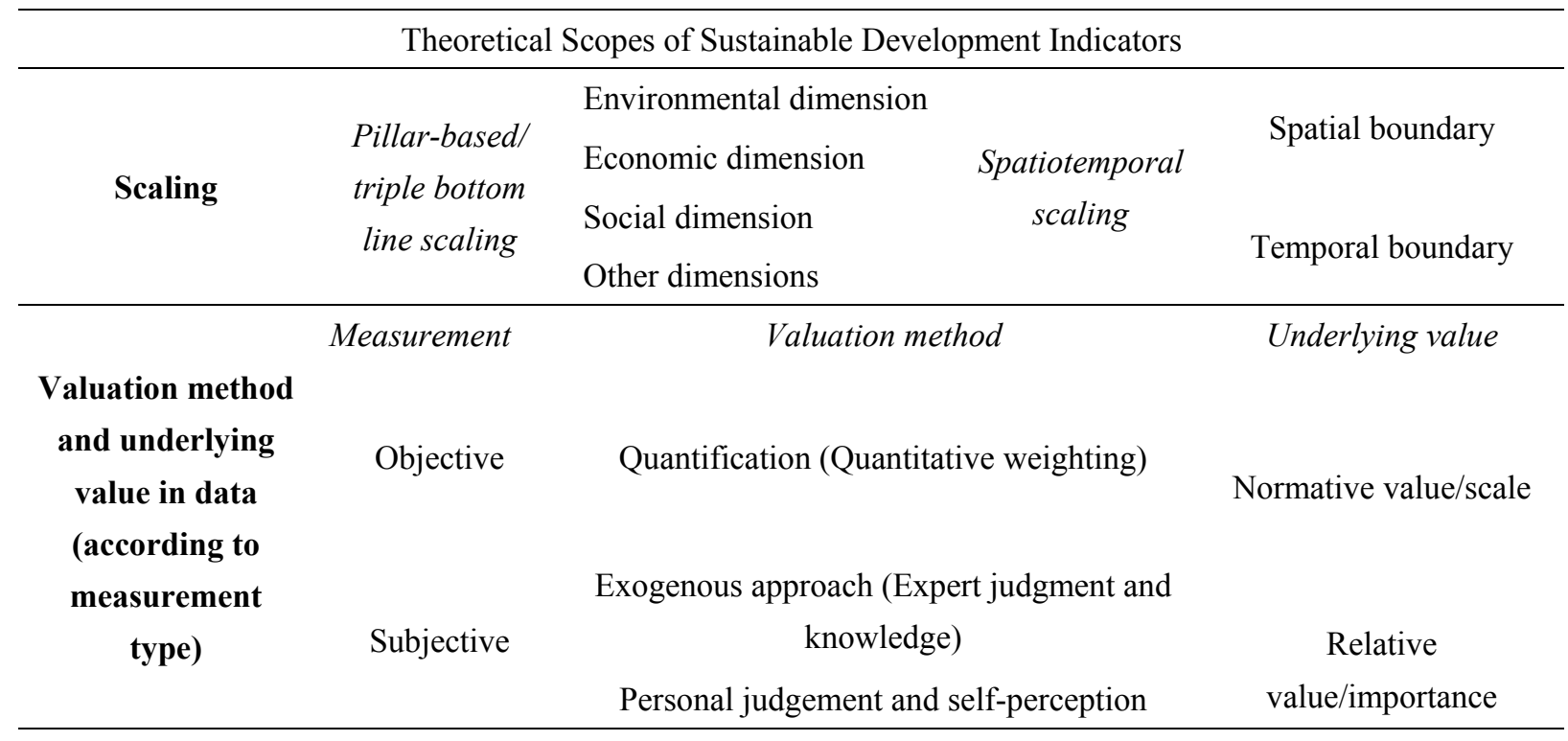


Given the conceptual and theoretical groundings, it is assumed that the objective and the two subjective SDIs identified tend to measure subjects representing associated basic human needs which attribute to corresponding WB (i.e., objective material and social WB and subjective WB), and thus respective SDIs could optimally capture and address the most relevant WB in the outcomes. The next section examines the assumption by exploring empirical materials and further specifies the respective SDI scopes.

\subsection{The Overarching, Conceptual Subjects to Be Measured: Sustainable Development, Well-Being, and Basic Human Needs}

The concept of SD aims to realise poverty alleviation, environmental protection, and social equitability alongside economic growth while acknowledging the need to improve well-being (WB) of the present generation in a way that contributes to the future generations (Kammerbauer et al., 2001; Mebratu, 1998; UNECE, 2008). In the context, the present generation pursues meet their basic human needs without precluding the future generations from enjoying the same benefits (Hopwood, Mellor, \& O’Brien, 2005; Ness, Urbel-Piirsalu, Anderberg, \& Olsson, 2007), whereby human need fulfillment is maintained over time (Munda, 2013; Nissi \& Sarra, 2018). Likewise, WB is also attained by fulfilling basic human needs (Schaubroeck \& Rugani, 2017). Kjell (2011) argues that a profound understanding of WB has evolved through studying and defining SD, outlining how WB positions in SD. Similarly, Moser (2009) suggests that SD must not only acknowledge the dependency of the human society on the environment but recognise and enhance individual and collective human WB. Here, a clear interrelation between SD and WB can be further explained through exploring the characteristics of basic human needs, assuming that these are regarded as the fundamental substances to be attained in both achieving SD and enhancing WB.

Basic human needs refer to primary basic rights, social goods, and socio-economic benefits (Bleys, 2012; Sirgy, 2011); including, for instance, nutrition (adequate food), clean air and water, shelter (protective houses), sanitation, basic medical care physical, economic, and occupational safety, safe environment, basic education, and human relationships (Doyle \& Perez-Alaniz, 2017; King, Renó, \& Novo, 2014). Basic human needs are generally considered to exist in a hierarchy, and the aforementioned needs are regarded as lower-order needs and its fulfillment contributes to meet higher-order needs, such as (self) esteem, self-actualisation, social needs (e.g., competence), aesthetic needs, psychological needs (psychological well-being), and a community's collective needs (King et al., 2014; Schaubroeck \& Rugani, 2017; Sirgy, 2011).

Given the multi-dimensionality and essentiality of basic (human) needs, they can be embedded in the concept of SD. SD is understood to comprise three pillars of the planet system (e.g., environmental, social, and economic) and can be achieved, considering their interdependency, interrelation, and interconnection, although each pillar is independently important (Bleys, 2012; Le Tourneau et al., 2013; Moser, 2009). Basic (human) needs in the environmental pillar (e.g., clean air and water) are fulfilled by enjoying natural resources and a healthy environment; and by sustaining ecosystem, given that the environmental pillar aims to secure ecosystem's productivity and capacity that respond to pressures, produced by human activity, such as exploiting natural resources and emitting pollutants (Bleys, 2012; Kjell, 2011; Sirgy, 2011). The social pillar considers social development and progress, whereby diverse social norms need to be realised over time, such as social cohesion, involvement, and justice, as well as equity between genders, social classes, and generation (Gallego-Álvarez, Galindo-Villardón, \& Rodríguez-Rosa, 2015; Moser, 2009; Ness et al., 2007; Ottaviani, 2018). Accordingly, it is assumed that basic needs in this pillar (e.g., (person's) social needs and community's collective needs) are characterised in relation to or based on the norms, and its persuasion contributes to meet the needs. In the economic pillar, basic needs primarily refer to securing a person's economic safety (e.g., a certain income level); additionally, several basic needs belonging to the other pillars can also be identified - explicitly associated with an economic aspect, given that this dimension endorses economic growth while minimising environmental degradation, conserving natural resources, and contributing to human development and equity, including poverty eradication (Doyle \& Perez-Alaniz, 2017; Gallego-Álvarez et al., 2015; Mayer et al., 2017).

Well-being is also understood as a multi-dimensional concept and often features the objective and subjective dimensions (Chaaban Irani, \& Khoury, 2016; D'Acci, 2011; Higgs, 2007; Jordan et al. 2010; King et al. 2014; Loring, Hinzman, \& Neufeld, 2016; Villamagna \& Giesecke, 2014; Wang, Kang, \& Yu, 2018). Objective WB entails material and social attributions in relation to person's life circumstances (King et al., 2014). First, material WB is met by achieving a certain level of material satisfaction or utility; it includes material needs for a life basis and safety, such as sufficient food, access to ecosystem service (e.g., clean air and water), and material conditions and possessions (D'Acci, 2011; Loring et al., 2016). Second, social WB is attained through meeting social needs which contribute to a person's social life, such as social- connection and relationships, participation, educational conditions, and freedom; and collective needs, including social cohesion, civil engagement, social equity, collective association, and political representation (Barrington-Leigh \& Escande, 2016; Bertin, Carrino, \& Give, 
2018; Ferrara \& Nisticó, 2013; Nissi \& Sarra, 2018; Raudsepp-Hearne et al., 2010; Villamagna \& Giesecke, 2014). In contrast, subjective WB is addressed through an individual's perception, experience, feelings, or level of satisfaction with life circumstances and attained by meeting perceived and psychological needs (e.g., self-esteem); it is frequently used interchangeably with similar concepts, such as quality of life, life satisfaction, or happiness (D'Acci, 2011; Diener \& Sue, 1997; King et al., 2014; Moser, 2009; Wang et al., 2018). It is argued that a person's material need condition influences their subjective WB. For instance, a higher income contributes to greater subjective WB (King et al., 2014; Hamann, Biggs, \& Reyers, 2016; Zorrilla-Miras et al., 2018). However, examining an interrelation between the differentiated WB is out of this study's scope, given its focus on clarifying the conceptual characteristics and association to the given indicator systems.

Accordingly, basic human needs are substantially embedded in SD and WB as their fundamental substances to be attained and maintained, and identifying the common needs helps conceptually interrelate the two concepts, while subjective WB needs to be further incorporated in the context of SD. Nevertheless, measuring several elements of subjective WB may not be feasible in long-term SD assessment, such as an individual's emotional response or affection towards their life circumstances (Diener \& Sue 1997).

\section{Empirical Findings: Examining the Characteristics of Three Distinctive SDI Measurements, Measuring Differentiated WB by Exploring Sustainable Development and Well-Being Assessment Practices}

In this section, major indicators employed in state-of-the-art practices of SD and WB indicator-based assessment are examined, whereby the overall trends of the three SDIs, complemented by examining indicators measuring the most relevant WB are highlighted, according to a pillar-based categorisation.

\subsection{Objective Indicator Trends: An Objective Approach and Measuring Material Well-Being}

Table 3 presents major SDIs using quantification of subjects, while Table 4 features major indicators measuring objective material WB. Note that the individual indicators and 'other pillars' in the tables through this section are classified, based on the original studies' categorisations. The results highlight the two primary trends, corresponding with the theoretical findings. First, the existing indicators are frequently referred to in both assessments; for instance, the environmental indicator ecological footprint, the social indicator life expectancy, and the economic indicators GDP and income gap (referring to Gini coefficient). Second, most indicators quantitatively weight variables, referring to publicly available statistic data; for instance, environmental indicators GHG, water, and air, social indicators education, including literacy, health, safety, and population and economic indicators (un)employment, and income. Furthermore, the results also suggest that most objective SDIs - in particular, the environmental and economic indicators - represent material needs (e.g., clean air and water and income), while WB indicators represent basic human needs (e.g., house, clothing, and food) which are seen merely in WB assessment. Alternatively, several indicators measure subjects based on not inherently objective concepts, such as biodiversity, and (good) governance by quantifying the variables, which appear merely in SD assessment. The trends resonate with the conceptual findings: The indicators highlighted incorporate indicators often employed in upper-level assessments into local practices, whereby it plays a role to understand the universal issues (e.g., $G H G$ emission), according to the local contexts.

Table 3. Sustainable development assessment research subjects and major objective indicators identified in the literature analysed (Note that the abbreviations represent specific indicator items; water: water quality, pollution, or usage; air: air quality or pollution; biodiversity: number of species, change of landscape; education: educational level, school enrolment; population: numerical population or growth)

\begin{tabular}{|c|c|c|c|c|c|}
\hline \multirow{2}{*}{ Reference } & \multirow{2}{*}{ Study Subject } & \multicolumn{4}{|c|}{ Example of Sustainable Development Indicators According to Pillar-Based Categorisation } \\
\hline & & Environmental & Social & Economic & Other \\
\hline $\begin{array}{l}\text { Alfaro-Navarro et } \\
\text { al. (2017) }\end{array}$ & $\begin{array}{l}\text { Sustainable } \\
\text { urbanisation }\end{array}$ & $\begin{array}{l}\text { Water, Air, Land } \\
\text { use, Waste } \\
\text { management }\end{array}$ & $\begin{array}{l}\text { Safety, } \\
\text { Education }\end{array}$ & GDP, (Un)employment & - \\
\hline $\begin{array}{l}\text { Dobrovolskiiené } \\
\& \quad \text { Tamošiūniené } \\
(2016)\end{array}$ & $\begin{array}{l}\text { Sustainable } \\
\text { construction }\end{array}$ & $\begin{array}{l}\text { GHG, Water, } \\
\text { Renewable energy }\end{array}$ & $\begin{array}{l}\text { Worker safety \& } \\
\text { health, } \\
\text { training }\end{array}$ & Maintenance cost & - \\
\hline $\begin{array}{l}\text { Estoque \& } \\
\text { Murayama (2014) }\end{array}$ & $\begin{array}{l}\text { Sustainable } \\
\text { urbanisation }\end{array}$ & $\begin{array}{l}\text { Ecological } \\
\text { footprint }\end{array}$ & $\begin{array}{l}\text { Life expectancy, } \\
\text { Education, }\end{array}$ & Income, Poverty & - \\
\hline
\end{tabular}




\begin{tabular}{|c|c|c|c|c|c|}
\hline & & & Population & & \\
\hline $\begin{array}{l}\text { Floridi et al. } \\
\text { (2011) }\end{array}$ & $\begin{array}{l}\text { Regional } \\
\text { sustainable } \\
\text { development } \\
\end{array}$ & $\begin{array}{l}\text { GHG, Air, } \\
\text { Renewable energy } \\
\text { use }\end{array}$ & $\begin{array}{l}\text { Life expectancy, } \\
\text { Safety (traffic), } \\
\text { Education }\end{array}$ & $\begin{array}{l}\text { GDP, } \\
\text { (Un)employment, } \\
\text { Income gap }\end{array}$ & - \\
\hline $\begin{array}{l}\text { Gallego-Álvarez } \\
\text { et al. (2015) }\end{array}$ & $\begin{array}{l}\text { Sustainable } \\
\text { development } \\
\text { indicator study }\end{array}$ & $\begin{array}{l}\text { GHG, Air, Water, } \\
\text { Renewable energy } \\
\text { use, Biodiversity }\end{array}$ & $\begin{array}{l}\text { Health, Education, } \\
\text { Sufficient } \\
\text { food/drink, Gender } \\
\text { equity }\end{array}$ & GDP, Employment & $\begin{array}{c}\text { Good governance } \\
\text { [Governance] }\end{array}$ \\
\hline $\begin{array}{l}\text { Gómez-Limón \& } \\
\text { Sanchez- } \\
\text { Fernandez (2010) }\end{array}$ & $\begin{array}{l}\text { Agricultural } \\
\text { sustainability }\end{array}$ & $\begin{array}{l}\text { Water, Erosion, } \\
\text { Biodiversity }\end{array}$ & $\begin{array}{l}\text { Population } \\
\text { (agricultural) }\end{array}$ & $\begin{array}{l}\text { GDP, Employment, } \\
\text { Income }\end{array}$ & - \\
\hline Hara et al. (2009) & $\begin{array}{l}\text { Sustainable } \\
\text { development } \\
\text { indicator study }\end{array}$ & $\begin{array}{l}\text { Water, Air, Green } \\
\text { space, Waste } \\
\text { management }\end{array}$ & $\begin{array}{l}\text { Life expectancy, } \\
\text { Literacy }\end{array}$ & $\begin{array}{l}\text { GDP, Employment, } \\
\text { Income gap }\end{array}$ & - \\
\hline Li et al. (2012) & $\begin{array}{l}\text { Sustainable } \\
\text { manufacturing }\end{array}$ & $\begin{array}{l}\text { GHG, Air, } \\
\text { Renewable energy } \\
\text { use, Waste } \\
\text { management }\end{array}$ & $\begin{array}{l}\text { Worker health, } \\
\text { Worker training, } \\
\text { Gender equity }\end{array}$ & $\begin{array}{l}\text { Legal costs, } \\
\text { investments (human } \\
\text { and natural resources) }\end{array}$ & - \\
\hline $\begin{array}{l}\text { Moctezuma- } \\
\text { Malagón et al. } \\
(2008)\end{array}$ & $\begin{array}{l}\text { Sustainability of } \\
\text { wetland }\end{array}$ & $\begin{array}{l}\text { Water, Land use, } \\
\text { Biodiversity }\end{array}$ & $\begin{array}{l}\text { Participation, } \\
\text { Gender equity }\end{array}$ & Income & - \\
\hline Phillis et al. (2011) & $\begin{array}{l}\text { Sustainable } \\
\text { development } \\
\text { indicator study }\end{array}$ & $\begin{array}{l}\text { Water, Air, Land } \\
\text { use, Biodiversity }\end{array}$ & $\begin{array}{l}\text { Life expectancy, } \\
\text { Education, } \\
\text { Population }\end{array}$ & $\begin{array}{l}\text { GDP, Unemployment, } \\
\text { Poverty }\end{array}$ & $\begin{array}{l}\text { Political rights, } \\
\text { Governance[Political] }\end{array}$ \\
\hline $\begin{array}{l}\text { Pop \& Borza } \\
(2016)\end{array}$ & $\begin{array}{l}\text { Sustainability of } \\
\text { museum }\end{array}$ & $\begin{array}{l}\text { Water, Energy } \\
\text { consumption }\end{array}$ & $\begin{array}{l}\text { Worker productivity, } \\
\text { Volunteer work }\end{array}$ & $\begin{array}{l}\text { Efficient financial } \\
\text { resource use }\end{array}$ & - \\
\hline Shmelev (2011) & $\begin{array}{l}\text { Inter-regional } \\
\text { sustainable } \\
\text { development } \\
\text { assessment } \\
\end{array}$ & $\begin{array}{l}\text { GHG, Water, } \\
\text { Renewable energy } \\
\text { use, } \quad \text { Energy } \\
\text { consumption }\end{array}$ & $\begin{array}{l}\text { Life expectancy, } \\
\text { Safety (crime) }\end{array}$ & $\begin{array}{l}\text { GDP, Unemployment, } \\
\text { Income gap }\end{array}$ & - \\
\hline $\begin{array}{l}\text { Shmelev \& } \\
\text { Rodrígues- } \\
\text { Labajos (2009) }\end{array}$ & $\begin{array}{l}\text { Multidimensional } \\
\text { assessment of } \\
\text { sustainability }\end{array}$ & $\begin{array}{l}\text { GHG, Water, } \\
\text { Renewable energy } \\
\text { use, } \quad \text { Energy } \\
\text { consumption }\end{array}$ & $\begin{array}{l}\text { Life expectancy, } \\
\text { Safety(crime), } \\
\text { Education, } \\
\text { Population }\end{array}$ & $\begin{array}{l}\text { GDP, Unemployment, } \\
\text { Income gap }\end{array}$ & $\begin{array}{l}\text { Research and } \\
\text { development } \\
\text { [Institutional] }\end{array}$ \\
\hline $\begin{array}{l}\text { Strezov et al. } \\
(2017)\end{array}$ & $\begin{array}{l}\text { Sustainable } \\
\text { development } \\
\text { indicator study }\end{array}$ & $\begin{array}{l}\text { GHG, Air, Water, } \\
\text { Ecological } \\
\text { footprint }\end{array}$ & $\begin{array}{l}\text { Life expectancy, } \\
\text { Education, Gender } \\
\text { equality }\end{array}$ & GDP, Income, Poverty & $\begin{array}{l}\text { Good governance } \\
\text { [Governance] }\end{array}$ \\
\hline $\begin{array}{l}\text { Talukder et al. } \\
(2017)\end{array}$ & $\begin{array}{l}\text { Sustainable } \\
\text { agriculture }\end{array}$ & Water, Land use & $\begin{array}{l}\text { Health, Education, } \\
\text { Gender equity }\end{array}$ & $\begin{array}{l}\text { Income, Economic } \\
\text { equity }\end{array}$ & - \\
\hline Yang et al. (2014) & $\begin{array}{l}\text { Inter-regional } \\
\text { sustainable } \\
\text { development } \\
\text { assessment }\end{array}$ & $\begin{array}{l}\text { Air, Land use, } \\
\text { Waste management }\end{array}$ & $\begin{array}{l}\text { Education, } \\
\text { Population }\end{array}$ & $\begin{array}{l}\text { GDP, Unemployment, } \\
\text { Income gap }\end{array}$ & - \\
\hline
\end{tabular}


Table 4. Major indicators, measuring objective material well-being, identified in the literature analysed (Note that a study that uses indicators measuring different well-being is referred to accordingly in Table 6 and 8)

\begin{tabular}{|c|c|c|c|c|c|}
\hline \multirow{2}{*}{ Reference } & \multirow{2}{*}{$\begin{array}{l}\text { Well-being } \\
\text { Attribution }\end{array}$} & \multicolumn{4}{|c|}{ Examples of Well-being Indicators According to Pillar-Based Categorisation } \\
\hline & & Environmental & Social & Economic & Other \\
\hline Chaaban et al. (2016) & & Air & $\begin{array}{c}\text { Safety, Life } \\
\text { expectancy, Education, } \\
\text { Housing }\end{array}$ & $\begin{array}{l}\text { (Un)employment, } \\
\text { Income }\end{array}$ & - \\
\hline D’Acci (2011) & & - & $\begin{array}{l}\text { Life expectancy, } \\
\text { Education, Gender } \\
\text { equity }\end{array}$ & $\begin{array}{c}\text { GDP, } \\
\text { Unemployment, } \\
\text { Income gap }\end{array}$ & $\begin{array}{c}\text { Cultural-scientific } \\
\text { progress (Research } \\
\text { \& development), } \\
\text { Human progress } \\
\text { (Freedom) }\end{array}$ \\
\hline $\begin{array}{l}\text { Ferrara \& Nisticó } \\
(2013)\end{array}$ & & Waste management & $\begin{array}{l}\text { Life expectancy, } \\
\text { Education, Social } \\
\text { equity (opportunity) }\end{array}$ & $\begin{array}{l}\text { GDP, Income, } \\
\text { (Un)employment }\end{array}$ & - \\
\hline Hamann et al. (2016) & & Water & $\begin{array}{l}\text { Life expectancy, } \\
\text { Education }\end{array}$ & $\begin{array}{c}\text { Income, } \\
\text { Unemployment }\end{array}$ & - \\
\hline Loring et al. (2016) & & - & Education & Income & - \\
\hline Nissi \& Sarra (2018) & & Water, Air & $\begin{array}{l}\text { Life expectancy, } \\
\text { Education }\end{array}$ & $\begin{array}{c}\text { Income, } \\
\text { Unemployment }\end{array}$ & - \\
\hline Ottaviani (2018) & & Air & Food, Housing & Income gap & - \\
\hline Schimmel (2009) & & - & - & Income & - \\
\hline Segre et al. (2011) & & $\begin{array}{l}\text { Water, Air, Land } \\
\text { use, Waste } \\
\text { management }\end{array}$ & $\begin{array}{c}\text { Housing, Basic service } \\
\text { access }\end{array}$ & $\begin{array}{c}\text { Unemployment, } \\
\text { Income gap, Poverty }\end{array}$ & - \\
\hline Sirgy (2011) & & $\begin{array}{l}\text { Air, Water, Land } \\
\text { use, Energy } \\
\text { consumption }\end{array}$ & $\begin{array}{l}\text { Health, Population, } \\
\text { Food, Housing }\end{array}$ & $\begin{array}{c}\text { Income, } \\
\text { Employment, } \\
\text { Poverty }\end{array}$ & - \\
\hline $\begin{array}{l}\text { Zorondo-Rodrígues et } \\
\text { al. (2014) }\end{array}$ & & - & $\begin{array}{c}\text { Food, Clothing, } \\
\text { Property }\end{array}$ & - & - \\
\hline
\end{tabular}

\subsection{Subjective Indicator Trends: An Exogenous Approach and Capturing Social Well-Being}

Table 5 presents major SDIs, which rely on an exogenous approach measurement, while Table 6 presents major indicators measuring social WB. In this context, experts represent practitioners, such as representatives of a local authority, professional advisers, or scholars from the given fields. The results indicate two major trends. First, most indicators intend to measure subjects representing social and collective needs, whose fulfillment influences on a community's WB. For example, environmental indicators regarding environmental management and protection, social indicators community involvement, and social- development, cohesion, equity, and engagement, and economic indicators economic prosperity, income/economic equity, and business cooperation/collaboration. Second, several indicators feature an intersectoral scope, such that the outcomes have an impact across the pillars. For example, the outcome of environmental management initiatives indicator can influence across the environmental and social domains as do economic indicators income equity and economic partnership across the social and economic dimensions. Likewise, the customer satisfaction with green products indicator produces the outcome which can influence across all pillars. Alternatively, in assessing social WB social indicators measuring education and social ties (e.g., support network and social cohesion) are most often employed, whereas only three environmental and one economic indicators are observed. It is noted that an indicator education is observed in 
measuring social WB, although its measurement is often identical to the objective SDIs of which. This is due to that the outcome is expected to contribute to meet social WB in this context. Similarly, several indicators employed in the objective approach (e.g., biodiversity, water, and health) are also confirmed. Nevertheless, the outcomes reflect local reality as the conceptual findings suggest, thus these indicators are more tailor-made to the local contexts by this approach.

Table 5. Sustainable development assessment research subjects and major indicators, relying on expert knowledge and judgement, identified in the literature analysed (Note that 1 indicates indirect assessments through an evaluation of the indicator system, and 2 indicates joint evaluation by experts and local residents through a workshop)

\begin{tabular}{|c|c|c|c|c|c|}
\hline \multirow{2}{*}{ Reference } & \multirow{2}{*}{ Study Subject } & \multicolumn{4}{|c|}{ Example of Sustainable Development Indicators According to Pillar-Based Categorisation } \\
\hline & & Environmental & Social & Economic & Other \\
\hline $\begin{array}{c}\text { Bhandari }{ }^{1} \text { et al. } \\
\text { (2018) }\end{array}$ & $\begin{array}{c}\text { Sustainable } \\
\text { community micro } \\
\text { hydro-power } \\
\text { plant }\end{array}$ & $\begin{array}{c}\text { Legislation } \\
\text { compliance, Impact } \\
\text { on environment, } \\
\text { Environmental } \\
\text { management }\end{array}$ & $\begin{array}{c}\text { Community } \\
\text { involvement, Social } \\
\text { stability, User } \\
\text { satisfaction }\end{array}$ & $\begin{array}{c}\text { Employment } \\
\text { opportunity, } \\
\text { Business potential }\end{array}$ & $\begin{array}{c}\text { Serviceability of } \\
\text { energy supply, } \\
\text { Expansion } \\
\text { possibility } \\
\text { [Technical] }\end{array}$ \\
\hline Gill et al. (2016) & $\begin{array}{l}\text { Sustainability } \\
\text { management of } \\
\text { contaminated } \\
\text { land }\end{array}$ & $\begin{array}{c}\text { Water, Erosion, } \\
\text { Ecology }\end{array}$ & $\begin{array}{l}\text { Neighbourhood \& } \\
\text { locality, Community } \\
\text { involvement. Ethics }\end{array}$ & $\begin{array}{l}\text { Employment } \\
\text { capacity }\end{array}$ & - \\
\hline $\begin{array}{c}\text { Gopal \& Thakkar } \\
\text { (2015) }\end{array}$ & $\begin{array}{l}\text { Sustainable } \\
\text { supply chain }\end{array}$ & $\begin{array}{c}\text { Environmental } \\
\text { management } \\
\text { initiatives, } \\
\text { Availability of } \\
\text { evaluation/reward } \\
\text { system }\end{array}$ & $\begin{array}{l}\text { Worker health \& } \\
\text { safety, Corruption, } \\
\text { Customer satisfaction } \\
\text { with green products }\end{array}$ & $\begin{array}{c}\text { Revenue } \\
\text { improvement, } \\
\text { Recycle cost }\end{array}$ & $\begin{array}{c}\text { New technology } \\
\text { adaption } \\
\text { [Technological], } \\
\text { Political stability } \\
\text { [Political] }\end{array}$ \\
\hline Haider et al. (2018) & $\begin{array}{l}\text { Neighbourhood } \\
\text { sustainable } \\
\text { development }\end{array}$ & $\begin{array}{c}\text { Environmental } \\
\text { quality, Natural land } \\
\text { protection }\end{array}$ & $\begin{array}{c}\text { Social WB, Public } \\
\text { mobility \& } \\
\text { accessibility }\end{array}$ & $\begin{array}{l}\text { Economic } \\
\text { prosperity }\end{array}$ & - \\
\hline $\begin{array}{l}\text { Herrera }^{1,2} \text { et al. } \\
\text { (2016) }\end{array}$ & $\begin{array}{l}\text { Sustainable } \\
\text { farming }\end{array}$ & $\begin{array}{c}\text { Farm management \& } \\
\text { practices, Ecology }\end{array}$ & $\begin{array}{c}\text { Social engagement, } \\
\text { Social diversification, } \\
\text { Quality of life }\end{array}$ & $\begin{array}{c}\text { Market } \\
\text { diversification, } \\
\text { Investment } \\
\text { modernisation }\end{array}$ & - \\
\hline Peano et al. (2015) & $\begin{array}{l}\text { Sustainable agri- } \\
\text { food system }\end{array}$ & $\begin{array}{l}\text { Landscape } \\
\text { conservation, } \\
\text { Biodiversity }\end{array}$ & $\begin{array}{c}\text { Education, } \\
\text { Relationship with } \\
\text { externals }\end{array}$ & $\begin{array}{c}\text { Market } \\
\text { diversification, } \\
\text { Economic } \\
\text { partnership }\end{array}$ & $\begin{array}{l}\text { Architectural } \\
\text { cultural assets. } \\
\text { Knowledge } \\
\text { transmission } \\
\text { [Cultural] }\end{array}$ \\
\hline Pinar et al. (2014) & $\begin{array}{c}\text { Sustainable } \\
\text { development } \\
\text { indicator study }\end{array}$ & $\begin{array}{c}\text { Biodiversity, Energy } \\
\text { intensity }\end{array}$ & $\begin{array}{c}\text { Health, Education, } \\
\text { Energy security }\end{array}$ & $\begin{array}{l}\text { Investment, } \\
\text { Research \& } \\
\text { development }\end{array}$ & - \\
\hline Sadok et al. (2009) & $\begin{array}{c}\text { Sustainable } \\
\text { cropping system }\end{array}$ & $\begin{array}{c}\text { Environmental } \\
\text { quality \& impact, } \\
\text { Biodiversity }\end{array}$ & $\begin{array}{c}\text { Health risks, } \\
\text { Operational } \\
\text { difficulties }\end{array}$ & $\begin{array}{l}\text { Profitability, } \\
\text { Specific } \\
\text { equipment needs }\end{array}$ & - \\
\hline $\begin{array}{c}\text { Schneider et al. } \\
\text { (2015) }\end{array}$ & $\begin{array}{c}\text { Sustainable water } \\
\text { governance }\end{array}$ & $\begin{array}{c}\text { Water, Resource } \\
\text { efficiency }\end{array}$ & $\begin{array}{l}\text { Learning capacity, } \\
\text { Cooperation, Basic } \\
\text { needs (water), Justice }\end{array}$ & $\begin{array}{c}\text { Material \& } \\
\text { financial capitals }\end{array}$ & $\begin{array}{c}\text { Institutions and } \\
\text { entitlement } \\
\text { [Institutional] }\end{array}$ \\
\hline $\begin{array}{l}\text { Sureeyatanapas et al. } \\
\qquad(2015)\end{array}$ & $\begin{array}{l}\text { Corporate } \\
\text { sustainability in } \\
\text { manufacturing }\end{array}$ & $\begin{array}{c}\text { Management } \\
\text { commitment to } \\
\text { environmental } \\
\text { protection }\end{array}$ & $\begin{array}{l}\text { Social development } \\
\& \text { participation, } \\
\text { Social responsibility }\end{array}$ & $\begin{array}{l}\text { Income euity, } \\
\text { Business support } \\
\text { \& collaboration }\end{array}$ & $\begin{array}{l}\text { Conformance to } \\
\text { international } \\
\text { standard } \\
\text { [Institutional] }\end{array}$ \\
\hline Touzard et al. (2016) & $\begin{array}{l}\text { Sustainability } \\
\text { evaluation of } \\
\text { local wine chain }\end{array}$ & $\begin{array}{c}\text { Environment } \\
\text { conservation, Water- } \\
\text { use practice }\end{array}$ & $\begin{array}{l}\text { Social cohesion, Food } \\
\text { safety }\end{array}$ & $\begin{array}{l}\text { Business } \\
\text { cooperation, } \\
\text { Added value } \\
\text { distribution }\end{array}$ & - \\
\hline
\end{tabular}


Table 6. Major indicators, measuring objective social well-being, identified in the literature analysed (Note that a study that uses indicators measuring different well-being is referred to accordingly in Table 4 and 8)

\begin{tabular}{|c|c|c|c|c|c|}
\hline \multirow[b]{2}{*}{ Reference } & \multirow{2}{*}{$\begin{array}{c}\text { Well- } \\
\text { being } \\
\text { Attribution }\end{array}$} & \multicolumn{4}{|c|}{ Examples of Well-being Indicators According to Pillar-Based Categorisation } \\
\hline & & Environmental & Social & Economic & Other \\
\hline $\begin{array}{c}\text { Chaaban et al. } \\
\qquad(2016)\end{array}$ & \multirow{11}{*}{ Social } & - & $\begin{array}{c}\text { Support network, } \\
\text { Volunteering }\end{array}$ & - & - \\
\hline D’Acci (2011) & & - & $\begin{array}{c}\text { Education, Gender } \\
\text { equity }\end{array}$ & - & - \\
\hline $\begin{array}{c}\text { Ferrara \& } \\
\text { Nisticó (2013) }\end{array}$ & & - & $\begin{array}{c}\text { Education, Social equity } \\
\text { (opportunity) }\end{array}$ & - & - \\
\hline $\begin{array}{l}\text { Hamann et al. } \\
\qquad(2016)\end{array}$ & & - & Education & - & - \\
\hline $\begin{array}{l}\text { Loring et al. } \\
\qquad(2016)\end{array}$ & & - & Education & - & - \\
\hline $\begin{array}{l}\text { Ottaviani } \\
\text { (2018) }\end{array}$ & & - & $\begin{array}{c}\text { Social resources access, } \\
\text { Participation, Work life } \\
\text { balance }\end{array}$ & - & - \\
\hline $\begin{array}{l}\text { Petrosillo et al. } \\
\qquad(2013)\end{array}$ & & - & Soc. cohesion & - & - \\
\hline $\begin{array}{l}\text { Schimmel } \\
\text { (2009) }\end{array}$ & & - & $\begin{array}{c}\text { Education, Political \& } \\
\text { social condition, Social } \\
\text { relation }\end{array}$ & - & - \\
\hline $\begin{array}{l}\text { Segre et al. } \\
\qquad(2011)\end{array}$ & & $\begin{array}{c}\text { Environmental } \\
\text { illegality/management, } \\
\text { Sustainable mobility }\end{array}$ & - & $\begin{array}{c}\text { Education, } \\
\text { Participation, } \\
\text { Gender equity, } \\
\text { Social exclusion }\end{array}$ & $\begin{array}{c}\text { Political participation } \\
\text { [Institutional] }\end{array}$ \\
\hline Sirgy (2011) & & - & Social equity & Economic equity & $\begin{array}{c}\text { Culture } \\
\text { [Cultural }]\end{array}$ \\
\hline $\begin{array}{c}\text { Zorondo- } \\
\text { Rodrígues et al. } \\
\text { (2014) }\end{array}$ & & Healthy environment & $\begin{array}{l}\text { Social \& family } \\
\text { relationship }\end{array}$ & - & $\begin{array}{c}\text { Rights \& legal } \\
\text { system [Institutional] }\end{array}$ \\
\hline
\end{tabular}

\subsection{Subjective Indicator Trends: An Approach Based on Personal Evaluation and Capturing Subjective Well-Being}

Table 7 presents major SDIs, which rely on personal evaluation based on self-perception in the measurements, while Table 8 presents major indicators measuring subjective WB. In this context, individuals refer to those who reside or work in the study areas, whether or not on behalf of the interests of the studies. The results highlight an overarching trend that indicators measuring the degree of an individual's life satisfaction or their satisfaction with life issues are employed in numerous cases of both SD and WB assessments. In addition, several SD and WB indicators in all pillars measure subjects that explicitly represent perceived and psychological needs. For instance, environmental indicators environmental-awareness and association, social indicators aesthetic value and perceived/close relationship with other people, economic indicators economic vulnerability and perceived economic benefits, and other-pillar indicators responsibility for SD, and feeling stressed. Accordingly, the overarching trend suggests that the concept of subjective WB can be most explicitly addressed in SD assessment outcomes by using this approach. 
Table 7. Sustainable development assessment research subjects and major indicators, relying on individual's selfperception, identified in the literature analysed (Note that lindicates indirect assessments through evaluation of indicator system)

\begin{tabular}{|c|c|c|c|c|c|}
\hline \multirow{2}{*}{ Reference } & \multirow{2}{*}{ Study Subject } & \multicolumn{4}{|c|}{ Example of Sustainable Development Indicators According to Pillar-Based Categorisation } \\
\hline & & Environmental & Social & Economic & Other \\
\hline $\begin{array}{l}\text { Adams et al. } \\
\text { (2014) }\end{array}$ & $\begin{array}{c}\text { Community } \\
\text { engagement in } \\
\text { sustainable land-use }\end{array}$ & $\begin{array}{c}\text { Biodiversity, } \\
\text { Perceived } \\
\text { environmental quality }\end{array}$ & $\begin{array}{c}\text { Family support, } \\
\text { Leisure }\end{array}$ & $\begin{array}{l}\text { Job and income } \\
\text { satisfaction }\end{array}$ & - \\
\hline $\begin{array}{l}\text { Antwi }{ }^{1} \text { et al. } \\
\text { (2017) }\end{array}$ & $\begin{array}{c}\text { Sustainability } \\
\text { impact assessment } \\
\text { of local mining }\end{array}$ & $\begin{array}{c}\text { Perceived } \\
\text { environmental quality }\end{array}$ & $\begin{array}{c}\text { Aesthetic value, } \\
\text { Cultural landscape } \\
\text { loss, Perceived social } \\
\text { equity }\end{array}$ & $\begin{array}{c}\text { Income } \\
\text { diversification }\end{array}$ & $\begin{array}{c}\text { Local knowledge use } \\
\text { [Institutional] }\end{array}$ \\
\hline $\begin{array}{c}\text { Arceo \& } \\
\text { Granados- } \\
\text { Barba }(2010) \\
\end{array}$ & $\begin{array}{c}\text { Sustainable marine } \\
\text { protection }\end{array}$ & $\begin{array}{c}\text { Resource status } \\
\text { perception }\end{array}$ & $\begin{array}{c}\text { Perceived personal } \\
\text { capability, Social } \\
\text { vulnerability }\end{array}$ & $\begin{array}{c}\text { Job diversification, } \\
\text { Economic } \\
\text { vulnerability } \\
\end{array}$ & - \\
\hline $\begin{array}{c}\text { Bhuiyan \& } \\
\text { Siwar (2016) }\end{array}$ & Sustainable tourism & $\begin{array}{c}\text { Perceived } \\
\text { environmental } \\
\text { quality(residents), } \\
\text { Environmental } \\
\text { awareness (tourists) }\end{array}$ & $\begin{array}{l}\text { Tourism facility and } \\
\text { service } \\
\text { satisfaction(tourists) }\end{array}$ & $\begin{array}{c}\text { Income } \\
\text { satisfaction, } \\
\text { Economic } \\
\text { contribution to } \\
\text { nature (residents) }\end{array}$ & - \\
\hline $\begin{array}{l}\text { Blancas et al. } \\
\qquad(2011)\end{array}$ & Sustainable tourism & $\begin{array}{c}\text { Natural environment } \\
\text { satisfaction }\end{array}$ & Safety satisfaction & $\begin{array}{l}\text { Quality-price } \\
\text { relation } \\
\text { satisfaction } \\
\end{array}$ & - \\
\hline $\begin{array}{l}\text { Choi \& } \\
\text { Sirakaya } \\
(2005)\end{array}$ & $\begin{array}{l}\text { Sustainable } \\
\text { community tourism }\end{array}$ & $\begin{array}{l}\text { Biodiversity, Env. } \\
\text { regulations }\end{array}$ & $\begin{array}{l}\text { Participation, } \\
\text { Comfort }\end{array}$ & $\begin{array}{c}\text { Livelihood } \\
\text { diversification, } \\
\text { Econ. contribution }\end{array}$ & Quality of life \\
\hline $\begin{array}{l}\text { Kunasekaran, } \\
\text { et al. }(2017)\end{array}$ & Sustainable tourism & $\begin{array}{c}\text { Environmental } \\
\text { awareness (e.g., } \\
\text { cleanliness) }\end{array}$ & $\begin{array}{l}\text { Perceived } \\
\text { relationships }\end{array}$ & $\begin{array}{l}\text { Local economic } \\
\text { sustainability }\end{array}$ & - \\
\hline $\begin{array}{l}\text { Le Tourneau et } \\
\qquad a l .(2013)\end{array}$ & $\begin{array}{c}\text { Sustainable } \\
\text { development } \\
\text { assessment of } \\
\text { community projects }\end{array}$ & $\begin{array}{c}\text { Environmental } \\
\text { awareness/association }\end{array}$ & Life satisfaction & - & $\begin{array}{l}\text { Responsibility for } \\
\text { SD[Governance] }\end{array}$ \\
\hline $\begin{array}{l}\text { Smith et al. } \\
\text { (2017) }\end{array}$ & $\begin{array}{c}\text { Sustainable } \\
\text { agroecosystem }\end{array}$ & $\begin{array}{c}\text { Self-reported } \\
\text { environmental impact }\end{array}$ & $\begin{array}{l}\text { Self-reported social } \\
\text { equity/ connection, } \\
\text { Food security }\end{array}$ & $\begin{array}{c}\text { Self-reported } \\
\text { financial access }\end{array}$ & - \\
\hline $\begin{array}{l}\text { Wilson }^{1} \text { et al. } \\
\text { (2014) }\end{array}$ & $\begin{array}{c}\text { Sustainable waste } \\
\text { management }\end{array}$ & $\begin{array}{c}\text { Waste management } \\
\text { quality }\end{array}$ & $\begin{array}{c}\text { Social equity (e.g., } \\
\text { public service } \\
\text { distribution) }\end{array}$ & $\begin{array}{c}\text { Financial } \\
\text { sustainability }\end{array}$ & $\begin{array}{c}\text { Local institutional } \\
\text { coherence/capacity } \\
\text { [Institutional] }\end{array}$ \\
\hline
\end{tabular}


Table 8. Major indicators, measuring subjective well-being, identified in the literature analysed (Note that a study that uses indicators measuring different well-being is referred to accordingly in Table 4 and 6)

\begin{tabular}{|c|c|c|c|c|c|}
\hline \multirow{2}{*}{ Reference } & \multirow{2}{*}{$\begin{array}{l}\text { Well-being } \\
\text { Attribution }\end{array}$} & \multicolumn{4}{|c|}{ Examples of Well-being Indicators According to Pillar-Based Categorisation } \\
\hline & & Environmental & Social & Economic & Other \\
\hline Barrington- & & & & & \\
\hline Leigh \& & & - & - & - & Life satisfaction \\
\hline Escande (2016) & & & & & \\
\hline $\begin{array}{l}\text { Chaaban et al. } \\
\qquad \text { (2016) }\end{array}$ & & $\begin{array}{l}\text { Water quality } \\
\text { satisfaction }\end{array}$ & $\begin{array}{l}\text { Self-reported health, } \\
\text { Housing/public } \\
\text { transport satisfaction }\end{array}$ & - & $\begin{array}{c}\text { Life satisfaction (overall) } \\
\text { Political voice }\end{array}$ \\
\hline D’Acci (2011) & & - & - & - & $\begin{array}{c}\text { Subjective WB } \\
\text { (happiness) }\end{array}$ \\
\hline Higgs (2009) & & - & Close relationship & - & $\begin{array}{c}\text { Life satisfaction, Mental } \\
\text { state }\end{array}$ \\
\hline $\begin{array}{l}\text { Loring et al. } \\
\qquad(2016)\end{array}$ & Subjective & - & - & - & $\begin{array}{c}\text { Life satisfaction, } \\
\text { Happiness, Feeling } \\
\text { stressed }\end{array}$ \\
\hline Ottaviani (2018) & & $\begin{array}{l}\text { Perceived } \\
\text { environmental quality }\end{array}$ & $\begin{array}{l}\text { Mutual trust, } \\
\text { Education satisfaction }\end{array}$ & $\begin{array}{c}\text { Perceived income } \\
\text { equity, Job } \\
\text { satisfaction }\end{array}$ & $\begin{array}{l}\text { Feeling stressed, Self- } \\
\text { assertiveness }\end{array}$ \\
\hline $\begin{array}{l}\text { Petrosillo et al. } \\
\qquad \text { (2013) }\end{array}$ & & - & Sense of safety & - & - \\
\hline $\begin{array}{l}\text { Schimmel } \\
\text { (2009) }\end{array}$ & & - & - & - & $\begin{array}{c}\text { Happiness, Self } \\
\text { confidence }\end{array}$ \\
\hline $\begin{array}{l}\text { Wang et al. } \\
\qquad(2018)\end{array}$ & & $\begin{array}{l}\text { Perceived urban } \\
\text { landscape quality }\end{array}$ & - & - & Life satisfaction \\
\hline
\end{tabular}

\section{Discussion: An Overview of the Distinctive Scopes and Functions of Objective and Expert-Led and Citizen- Based Subjective Sustainable Development Indicators}

Based on the conceptual, theoretical, and empirical findings, this section discusses the distinctive scopes and functions of objective SDIs and expert-led and citizen-based subjective SDIs, while providing the overview (see Figure 2). 


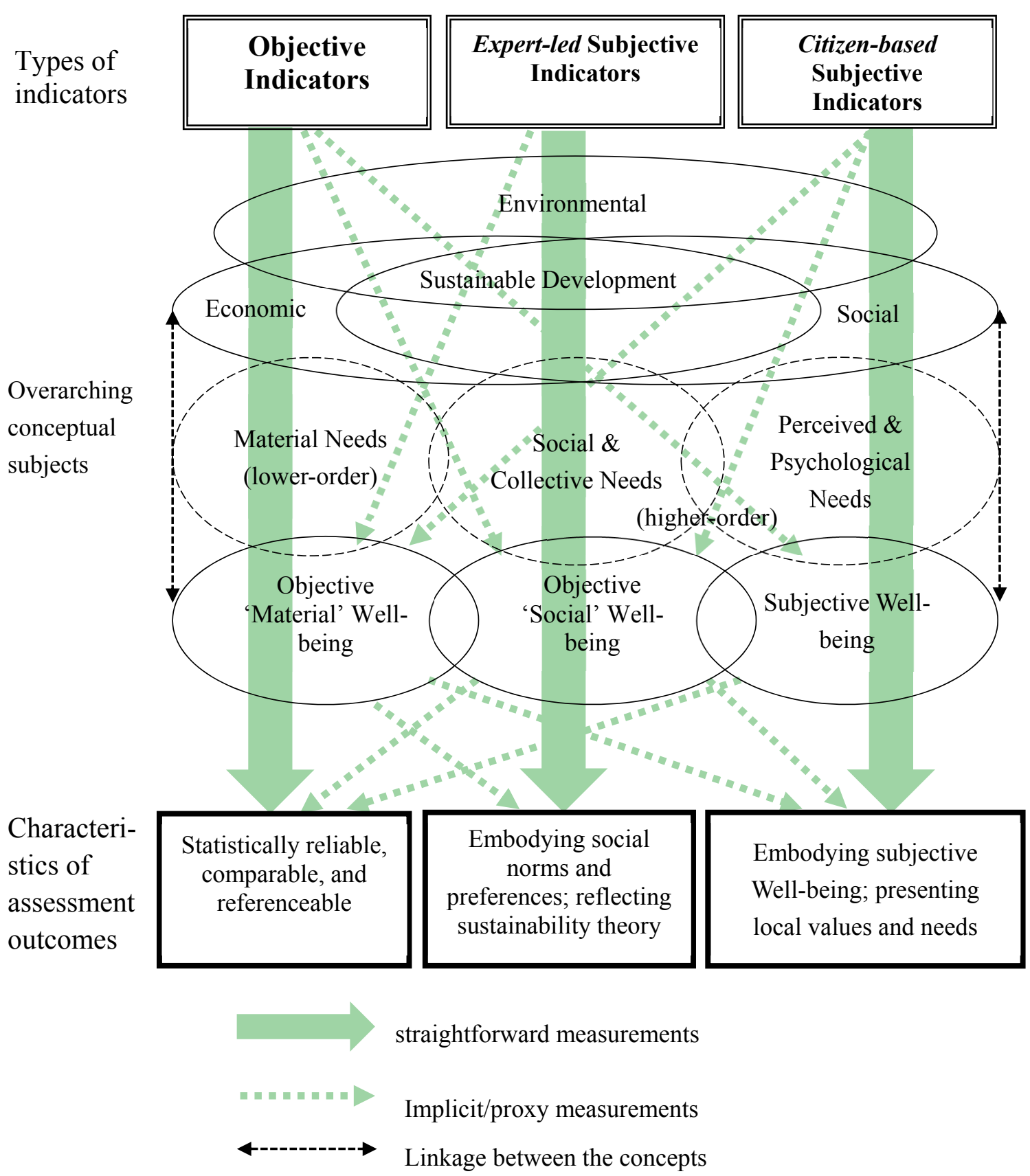

Figure 2. A distinctive characteristics of objective sustainable development indicators and expert-led and citizenbased subjective sustainable development indicators

The findings suggest that objective SDIs are most capable of measuring subjects that represent material needs corresponding to, for instance, physical environmental qualities, income levels, and life expectancy. Meanwhile, basic needs attributing to material WB, in particular, regarding life basis and material safety (e.g., housing and food) are frequently overlooked in SD assessment, thus need to be further incorporated in objective SDIs. The assessment outcomes produced by objective SDIs present referenceable and statistically reliable indicator values by referring to the existing indicators, such as GDP or publicly available statistics. Accordingly, the outcomes (data) are particularly applicable for a spatial comparison, given that the reference values are shared by different entities, and for ex-ante and post comparisons, given the temporal availability of the reference data.

Meanwhile, expert-led subjective SDIs (e.g., social cohesion, economic prosperity, and healthy environment) most 
optimally measure subjects that represent collective human and social needs, which attribute to and its fulfillment contributes to meet social WB, assuming that exogenous approach can incorporate social norms and preferences reflecting different dimensions of interests in developing indicators and delivering the assessment outcomes, which thus represents the heterogeneity of a community (Bertin et al., 2018; Raudsepp-Hearne et al., 2010; ReigMartínez, 2013). Moreover, this approach is frequently employed in measuring subjects based on multi-faceted concepts, which resonates with the theoretical findings: Using expert knowledge enables indicators to reflect sustainability theory and ensures the scientifical robustness of the measurement [and outcomes] (Graymore, 2014). For instance, the environmental indicator healthy environment echoes the idea of environmental health, which understands environmental factors as significant determinants of human WB (Loring et al., 2016); likewise, the economic indicator economic equity represents economic welfare, which aims to develop the economy by understanding general social WB (Bley.s 2012). Accordingly, expert-led subjective SDIs and the assessment outcomes most reflect SD rationale and social norms and preferences recognised by a community.

Finally, the citizen-based subjective SDIs are most applicable for measuring an individual's (present) satisfaction level and subjects representing perceived and psychological needs, which significantly contributes to meet individual's subjective WB (Diener \& Sue, 1997; Moser, 2009). For instance, economic indicators, such as perceived income- satisfaction and equity, measure the relative impact of an individual's economic conditions on their life satisfaction (Diener \& Sue, 1997). Accordingly, incorporating this approach in SD assessment allows for capturing and addressing subjective WB in the outcomes, which several conventional SDIs have overlooked (Stiglitz et al., 2009).

The findings also highlight that the respective SDIs can implicitly capture the other dimensions of WB, while the characteristics of the outcomes remain based on the given measurements (see Figure 2). First, objective SDIs can measure and address social and subjective WB through quantifying subjects. For instance, an indicator education frequently relies on existing indicators or publicly available statistics, such as literacy rate or years in education, but enhancing the outcome conceptually contributes to meet social WB. Likewise, an individual's subjective WB with respect to the happiness level can be partially measured through gauging their income level, given the correlation between them, although exceeding a certain level of economic wealth does not significantly influence one's happiness (O'Neill, 2012). Second, expert-led subjective SDIs can measure material needs and material WB by utilising an expert's subjective evaluation in measurements. The empirical results present that this approach is frequently employed to indicators, such as biodiversity, water, and health, in a case that there are no reference values or relevant statistical data available. Finally, citizen-based subjective SDIs can measure subjects representing objective material and social WB. For instance, indicators income satisfaction and perceived environmental quality represent economic and environmental needs respectively, which can however influence on individual's perceived needs. This suggests that the fulfilments contribute to meet material WB, which are regarded as proxies of individual's subjective WB, assuming that subjective WB is frequently influenced by fulfilling material and other non-self-perceived basic needs (Schaubroeck \& Rugani, 2017; Sirgy, 2011). Alternatively, this approach helps identify and present local needs and locally embedded values in the assessment outcomes through incorporating local aspects in constructing indicators and measuring subjects (Graymore, 2014; Kammerbauer et al., 2001; Nissi \& Sarra, 2018; Zorrilla-Miras et al., 2018). This suggests that the outcomes can represent social WB, assuming that local needs and values are shaped by a consensus of individual's social needs (e.g., participation).

\section{Conclusion}

This study advocates that using objective indicators is inadequate to measure SD, given that the objective SDIs are conceptually optimal to capture material needs and material WB but limited or inaccurate to capture higherorder basic human needs and the other dimensions of WB. In contrast, using the expert-led and citizen-based subjective SDIs complements the shortcoming by capturing social and collective needs associated with social WB as well as perceived and psychological needs attributing to subjective WB, respectively. Accordingly, the complementary use of the three types of SDIs in the SD assessment practice is desirable, given that not all indicators measure subjects and progress at the same level (Sarriot, Ricca, Ryan, Basnet, \& Arscott-Mills, 2009). Hence, using the SDIs assessing (present) conditions of 'material' and subjective WB helps better recognise the WB of the current generation in the SD context, while using the SDIs assessing social WB and its enhancement in the long-term assessment helps depict the WB of the future generation (Barrington-Leigh \& Escande, 2016; Kammerbauer et al., 2001).

However, this study faces several limitations. First, the variety of the articles retrieved was subject to the constraints of the literature search, given that the search results could be limited by citation distribution (Cohen, 2017). Accordingly, literature relevant to this study's aim might have been found under different search conditions, 
such as city and urban SD. Second, several subjective indicators referred to in this study may have provided limited information for this study's discussion and characterising the subjective SDIs. This was due to that the subjective indicators are usually developed, taking into account specific aims or interests of the given studies, and the context dependency in developing and employing the indicators in each study was inevitable. Hence, overcoming the limitations by, for instance, elaborating a broader range of studies and indicators helps identify the conceptual and theoretical function and implications for the practical use of SDIs.

\section{References}

Adams, V. M., Pressey, R. L., \& Stoeckl, N. (2014). Navigating trade-offs in land-use planning: integrating human well-being into objective setting. Ecology and Society, 19(4), 53. https://doi.org/10.5751/ES-07168-190453

Alfaro-Navarro, L. J., López-Ruiz, R. V., \& Peña, N. D. (2017). A New Sustainability City Index Based on Intellectual Capital Approach. Sustainability, 9, 860. https://doi.org/10.3390/su9050860

Allen, C., Nejdawi, R., El-Baba, J., Hamati, K., Metternich, G., \& Wiedmann, T. (2017). Indicator-based assessments of progress towards the sustainable development goals (SDGs): a case study from the Arab region. Sustainability Science, 12, 975-989. https://doi.org/10.1007/s11625-017-0437-1

Antwi, K. E., Owusu-Banahene, W., Boakye-Danquah, J., Mensah, R., Tetteh, D. J., Nagao, M., \& Takeuchi, K. (2017). Sustainability assessment of mine-affected communities in Ghana: towards ecosystems and livelihood restoration. Sustainability Science, 12, 747-767. https://doi.org/10.1007/s11625-017-0474-9

Arceo, P., \& Granados-Barba, A. (2010). Evaluating sustainability criteria for a marine protected area in Veracruz, Mexico. Ocean \& Coastal Management, 53, 535-543. https://doi.org/10.1016/j.ocecoaman.2010.06.005

Barrington-Leigh, C., \& Escande, A. (2016). Measuring Progress and Well-Being: A Comparative Review of Indicators. Social Indicators Research, 135, 893-925. https://doi.org/10.1007/s11205-016-1505-0

Beemsterboer, S., \& Kemp, R. (2016). Sustainability Assessment of Technologies; in Sustainability Science. In H. Heinrichs et al. (Eds.), Springer Science+Business Media Dordrecht. https://doi.org/10.1007/978-94-017$7242-6 \_6$

Bertin, G., Carrino, L., \& Give, S. (2018). The Italian Regional Well-Being in a Multi-expert Non-additive Perspective. Social Indicators Research, 135, 15-51. https://doi.org/10.1007/s11205-016-1475-2

Bhandari, R., Sapalena, L. G., \& Kusch, W. (2018). Sustainability assessment of a micro hydropower plant in Nepal. Energy, Sustainability and Society, 8(3). https://doi.org/10.1186/s13705-018-0147-2

Bhuiyan, Md. A. H., Siwar, C., \& Ismail, S. M. (2016). Sustainability Measurement for Ecotourism Destination in Malaysia: A Study on Lake Kenyir, Terengganu. Social Indicators Research, 128, 1029-1045. https://doi.org/10.1007/s11205-015-1068-5

Blancas, F. J., Lozano-Oyola, M., González, M., Guerrero, F. M., \& Caballero, R. (2011). How to use sustainability indicators for tourism planning: The case of rural tourism in Andalusia (Spain). Science of the Total Environment, 412-413, 28-45. https://doi.org/10.1016/j.scitotenv.2011.09.066

Bleys, B. (2012). Beyond GDP: Classifying Alternative Measures for Progress. Social Indicators Research, 109(3), 355-376. https://doi.org/10.1007/s11205-011-9906-6

Chaaban, J., Irani, A., \& Khoury, A. (2016). The Composite Global Well-Being Index (CGWBI): A New MultiDimensional Measure of Human Development. Social Indicators Research, 129, 465-487. https://doi.org/10.1007/s11205-015-1112-5

Choi, C. H., \& Sirakaya, E. (2005). Measuring Residents' Attitude toward Sustainable Tourism: Development of Sustainable Tourism Attitude Scale. Journal of Travel Research, 43, 380-394. https://doi.org/10.1177/0047287505274651

Cohen, M. (2017). A Systematic Review of Urban Sustainability Assessment Literature. Sustainability, 9, 2048. https://doi.org/10.3390/su9112048

Costanza, R. (2005). Thinking Broadly About Costs and Benefits in Ecological Management. Integral Environmental Assessment and Management, 2(2), 166-173. https://doi.org/10.1002/ieam.5630020209

Craheix, D., Bergez, J. E., Angevin, F., Bockstaller, C., Bohanec, M., Colomb, B., ... Sadok, W. (2015). Guidelines to design models assessing agricultural sustainability, based upon feedbacks from the DEXi decision support system. Agronomy for Sustainable Development, 35, 1431-1447. https://doi.org/10.1007/s13593-015-03150

D'Acci, L. (2011). Measuring Well-Being and Progress. Social Indicators Research, 104, 47-65. 
https://doi.org/10.1007/s11205-010-9717-1

de Jonge, V. N., Pinto, R., \& Turner, R. K. (2012). Integrating ecological, economic and social aspects to generate useful management information under the EU Directives' 'ecosystem approach'. Ocean \& Coastal Management, 68, 169-188. https://doi.org/10.1016/j.ocecoaman.2012.05.017

Diener, E., \& Sue, E. M. (1997). Measuring quality of life: Economic, social, and subjective indicators. Social Indicators Research, 40, 189-216. https://doi.org/10.1023/A:1006859511756

Dobrovolskiiené, N., \& Tamošiūniené, R. (2016). An Index to Measure Sustainability of a Business Project in the Construction Industry: Lithuanian Case. Sustainability, 8, 14. https://doi.org/10.3390/su8010014

Doyle, E., \& Perez-Alaniz, M. (2017). From the Concept to the Measurement of Sustainable Competitiveness: Social and Environmental Aspects. Entrepreneurial Business and Economics Review, 5(4), 36-59. https://doi.org/10.15678/EBER.2017.050402

Estoque, C. R., \& Murayama, Y. (2014). Measuring Sustainability Based Upon Various Perspectives: A Case Study of a Hill Station in Southeast Asia. AMBIO, 43, 943-956. https://doi.org/10.1007/s13280-014-0498-7

Eurostat. (2014). Towards a harmonised methodology forstatistical indicators: Part 1: Indicator typologies and terminologies. European Union, 1-30.

Fasolo, L., Galetto, M., \& Turina, E. (2013). Pragmatic approach to evaluate alternative indicators to GDP. Quality \& Quantity, 47(2), 633-657. https://doi.org/10.1007/s11135-011-9537-7

Ferrara, A. R., \& Nisticó, R. (2013). Well-Being Indicators and Convergence Across Italian Regions. Applied Research Quality Life, 8, 15-44. https://doi.org/10.1007/s11482-012-9180-z

Floridi, M., Pagni, S., Falorni, S., \& Luzzati, T. (2011). An exercise in composite indicators construction: Assessing the sustainability of Italian regions. Ecological Economics, 70, 1440-1447. https://doi.org/10.1016/j.ecolecon.2011.03.003

Gallego-Álvarez, I., Galindo-Villardón, M. A., \& Rodríguez-Rosa, M. (2015). Analysis of the Sustainable Society Index Worldwide: A Study from the Biplot Perspective. Social Indicators Research, 120, 29-65. https://doi.org/10.1007/s11205-014-0579-9

Gill, T. R., Thornton, F. S., Harbottle, J. M., \& Smith, N. W. J. (2016). Sustainability assessment of electrokinetic bioremediation compared with alternative remediation options for a petroleum release site. Journal of Environmental Management, 184, 120-131. https://doi.org/10.1016/j.jenvman.2016.07.036

Gómez-Limón, J. A., \& Sanchez-Fernandez, G. (2010). Empirical evaluation of agricultural sustainability using composite indicators. Ecological Economics, 69, 1062-1075. https://doi.org/10.1016/j.ecolecon.2009.11.027

Gopal, C. R. P., \& Thakkar, J. (2015). Development of composite sustainable supply chain performance index for the automobile industry. International Journal of Sustainability Engineering, 8(6), 366-385. https://doi.org/10.1080/19397038.2014.947392

Graymore, M. L. M. (2014). Sustainability Reporting: An Approach to Get the Right Mix of Theory and Practicality for Local Actors. Sustainability, 6, 3145-3170. https://doi.org/10.3390/su6063145

Haider, H., Hewage, K., Umer, A., Ruparathna, R., Chhipi-Shrestha, G., Culver, K., Holland, M., Kay, J., \& Sadiq, R. (2018). Sustainability assessment framework for small-sized urban neighbourhoods: An application of fuzzy synthetic evaluation. Sustainable Cities and Society, 36, 21-32. https://doi.org/10.1016/j.scs.2017.09.031

Hamann, M., Biggs, R., \& Reyers, B. (2016). An Exploration of Human Well-Being Bundles as Identifiers of Ecosystem Service Use Patterns. PLOS ONE, 11(10), 1-20. https://doi.org/10.1371/journal.pone.0163476

Hara, K., Uwasu, M., Yabar, H., \& Zhang, H. (2009). Sustainability assessment with time-series scores: a case study of Chinese provinces. Sustainability Science, 4, 81-97. https://doi.org/10.1007/s11625-008-0061-1

Herrera, B., Gerster-Bentaya, M., \& Knierim, A. (2016). Stakeholders' perceptions of sustainability measurement at farm level. Study in Agricultural Economy, 118, 131-137. https://doi.org/10.7896/j.1625

Hezri, A. A., \& Dovers, S. R. (2006). Sustainability indicators, policy and governance: Issues for ecological economics. Ecological Economics, 60, 86-99. https://doi.org/10.1016/j.ecolecon.2005.11.019

Higgs, N. T. (2007). Measuring and understanding the well-being of South Africans Everyday quality of life in South Africa. Social Indicators Research, 81, 331-356. https://doi.org/10.1007/s11205-006-9012-3

Hopwood, B., Mellor, M., \& O’Brien, G. (2005). Sustainable Development: Mapping Different Approaches. 
Sustainable Development, 13, 38-52. https://doi.org/10.1002/sd.244

Jordan, S. J., Hayes, S. E., Yoskowitz, D., Smith, L. M., Summers, J. K., Russel, M., \& Benson, W. H. (2010). Accounting for Natural Resources and Environmental Sustainability: Linking Ecosystem Services to Human Well-Being. Environmental Science and Technology, 44, 1530-1536. https://doi.org/10.1021/es902597u

Kaklauskas, A., Zavadskas, K. E., Radzeviciene, A., Ubarte, I., Podviezko, A., Podvezko, V., ... Bucinskas, V. (2018). Quality of city life multiple criteria analysis. Cities, $72, \quad 82-93$. https://doi.org/10.1016/j.cities.2017.08.002

Kammerbauer, J., Cordoba, B., Escolán, R., Flores, S., Ramirez, V., \& Zeledón, J. (2001). Identification of development indicators in tropical mountainous regions and some implications for natural resource policy designs: an integrated community case study. Ecological Economics, 36, 45-60. https://doi.org/10.1016/S0921-8009(00)00206-8

King, M. F., Renó, V. F., \& Novo, M. L. M. E. (2014). The Concept, Dimensions and Methods of Assessment of Human Well-Being within a Socioecological Context: A Literature Review. Social Indicators Research, 116, 681-698. https://doi.org/10.1007/s11205-013-0320-0

Kjell, O. (2011). Sustainable Well-Being: A Potential Synergy Between Sustainability and Well-Being Research. Review of General Psychology, V15(3), 255-266. https://doi.org/10.1037/a0024603

Koop, S. H., \& van Leeuwen, C. J. (2015). Assessment of the Sustainability of Water Resources Management: A Critical Review of the City Blueprint Approach. Water Resource Management, 29, 5649-5670. https://doi.org/10.1007/s11269-015-1139-z

Kunasekaran, P., Gill, S. S., Ramachandran, S., Shuib, A., Baum, T., \& Afandi, S. H. M. (2017) Measuring Sustainable Indigenous Tourism Indicators: A Case of Mah Meri Ethnic Group in Carey Island, Malaysia. Sustainability, 9, 1256. https://doi.org/10.3390/su9071256

Latruffe, L., Diazabakana, A., Bockstaller, C., Desjeux, Y., Finn, J., Kelly, E., Ryan, M., \& Uthes, S. (2016). Measurement of sustainability in agriculture: a review of indicators. Study in Agricultural Economy, 118, $123-$ 130. https://doi.org/10.7896/j.1624

Le Tourneau, M. F., Marchand, G., Greissing, A., Nasuti, S., Droulers, M., Bursztyn, M., Léna, P., \& Dubreuil, V. (2013). Assessing the impacts of sustainable development projects in the Amazon: the DURAMAZ experiment. Sustainability Science, 8, 199-212. https://doi.org/10.1007/s11625-013-0200-1

Li, T., Zhang, H., Yuan, C., Liu, Z., \& Fan, C. (2012). A PCA-based method for construction of composite sustainability indicators. International Journal of Life Cycle Assessment, 17, $593-603$. https://doi.org/10.1007/s11367-012-0394-y

Loring, P. A., Hinzman, M. S., \& Neufeld, H. (2016). Can people be sentinels of sustainability? Identifying the linkages among ecosystem health and human well-being. FACETS, 1, 148-162. https://doi.org/10.1139/facets-2016-0022

Mayer, A., Haas, W., \& Wiedenhofer, D. (2017). How Countries' Resource Use History Matters for Human Wellbeing - An Investigation of Global Patterns in Cumulative Material Flows from 1950 to 2010. Ecological Economy, 134, 1-10. https://doi.org/10.1016/j.ecolecon.2016.11.017

Mebratu, D. (1998). Sustainability and Sustainable Development: Historical and Conceptual Review. Environmental Impact Assessment Review, 18, 493-520. https://doi.org/10.1016/S0195-9255(98)00019-5

Moctezuma-Malagón, A., González-Esquivel, E. C., De la Lanza-Espino, G., González-Rebeles, \& Islas, C. (2008). A methodology for evaluating the sustainability of inland wetland systems. Aquaculture International, 16, 525-537. https://doi.org/10.1007/s10499-007-9163-5

Morse, S., Vogiatzakis, I., \& Griffiths, G. (2011). Space and Sustainability. Potential for Landscape as a Spatial Unit for Assessing Sustainability. Sustainable Development, 19, 30-48. https://doi.org/10.1002/sd.418

Moser, G. (2009). Quality of life and sustainability: Toward person-environment congruity. Journal of Environmental Psychology, 29, 351-357. https://doi.org/10.1016/j.jenvp.2009.02.002

Munda, G. (2013). Beyond GDP: An Overview of Measurement Issues in Redefining 'Wealth'. Journal of Economic Survey, 29(3), 403-422. https://doi.org/10.1111/joes.12057

Ness, B., Urbel-Piirsalu, E., Anderberg, S., \& Olsson, L. (2007). Categorising tools for sustainability assessment. Ecological Economocs, 60, 498-508. https://doi.org/10.1016/j.ecolecon.2006.07.023

Nissi, E., \& Sarra, A. (2018). A Measure of Well-Being Across the Italian Urban Areas: An Integrated DEA- 
Entropy Approach. Social Indicators Research, 136, 1183-1209. https://doi.org/10.1007/s11205-016-1535-7

O'Neill, D. W. (2012). Measuring progress in the degrowth transition to a steady state economy. Ecological Economics, 84, 221-231. https://doi.org/10.1016/j.ecolecon.2011.05.020

Ottaviani, F. (2018). Time in the Development of Indicators on Sustainable Wellbeing: A Local Experiment in Developing Alternative Indicators. Social Indicators Research, 135, 53-73. https://doi.org/10.1007/s11205016-1489-9

Peano, C., Tecco, N., Dansero, E., Girgenti, V., \& Sottile, F. (2015). Evaluating the Sustainability in Complex AgriFood Systems: The SAEMETH Framework. Sustainability, 7, 6721-6741. https://doi.org/10.3390/su7066721

Phillis, Y. A., Grigoroudis, E., \& Kouikoglou, V. S. (2011). Sustainability ranking and improvement of countries. Ecological Economics, 70, 542-553. https://doi.org/10.1016/j.ecolecon.2010.09.037

Pinar, M., Cruciani, C., Giove, S., \& Sostero, M. (2014). Constructing the FEEM Sustainability Index: a Choquet integral application. Ecological Indicators, 39, 189-202. https://doi.org/10.1016/j.ecolind.2013.12.012

Pop, I. L., \& Borza, A. (2016). Factors Influencing Museum Sustainability and Indicators for Museum Sustainability Measurement. Sustainability, 8, 101. https://doi.org/10.3390/su8010101

Raudsepp-Hearne, C., Peterson, G. C., Tengö, M., Bennett, E. M., Holland, T., Benessaih, K., MacDonald, G. K., \& Pfeifer, L. (2010). Untangling the Environmentalist's Paradox: Why Is Human Well-being Increasing as Ecosystem Services Degrade? BioScience, 60, 576-589. https://doi.org/10.1525/bio.2010.60.8.4

Reed, M. S., Fraser, E. G. D., \& Dougill, A. J. (2006). An adaptive learning process for developing and applying sustainability indicators with local communities. Ecological Economics, 59, 406-418. https://doi.org/10.1016/j.ecolecon.2005.11.008

Reig-Martínez, E. (2013). Social and Economic Wellbeing in Europe and the Mediterranean Basin: Building an Enlarged Human Development Indicator. Social Indicators Research, 111, 527-547. https://doi.org/10.1007/s11205-012-0018-8

Sadok, W., Angevin, F., Bergez, E. J., Bockstaller, C., Colomb, B., Guichard, L., Reau, R., Messéan, A., \& Doré, T. (2009). MASC, a qualitative multi-attribute decision model for ex ante assessment of the sustainability of cropping systems. Agronomy for Sustainable Development, 29, 447-461. https://doi.org/10.1051/agro/2009006

Sarriot, E., Ricca, J., Ryan, L., Basnet, J., \& Arscott-Mills, S. (2009). Measuring sustainability as a programming tool for health sector investments: report from a pilot sustainability assessment in five Nepalese health districts. International Journal of Health Planning and Management, 24, 326-350. https://doi.org/10.1002/hpm.1012

Schaubroeck, T., \& Rugani, B. (2017). A Revision of What Life Cycle Sustainability Assessment Should Entail. Towards Modeling the Net Impact on Human Well-Being. Journal of Industrial Ecology, 21(6), 1464-1477. https://doi.org/10.1111/jiec. 12653

Schimmel, J. (2009). Development as Happiness: The Subjective Perception of Happiness and UNDP's Analysis of Poverty, Wealth and Development. Journal of Happiness Studies, 10, 93-111. https://doi.org/10.1007/s10902-007-9063-4

Schneider, F., Bonriposi, M., Graefe, O., Herweg, K., Homewood, C., Huss, M., ... Weingartner, R. (2015). Assessing the sustainability of water governance systems: the sustainability wheel. Journal of Environmental Planning and Management, 58(9), 1577-1600. https://doi.org/10.1080/09640568.2014.938804

Segre, E., Rondinella, T., \& Mascherini, M. (2011). Well-Being in Italian Regions. Measures, Civil Society Consultation and Evidence. Social Indicators Research, 102, 47-69. https://doi.org/10.1007/s11205-0109722-4

Shmelev, E. S. (2011). Dynamic sustainability assessment: The case of Russia in the period of transition (19852008). Ecological Economics, 70, 2039-2049. https://doi.org/10.1016/j.ecolecon.2011.06.003

Shmelev, E. S., \& Rodrígues-Labajos, B. (2009). Dynamic multidimensional assessment of sustainability at the macro level: The case of Austria. Ecological Economics, 68, 2560-2573. https://doi.org/10.1016/j.ecolecon.2009.03.019

Singh, K. R., Murty, R. H., Gupta, K. S., \& Dikshit, K. A. (2012). An overview of sustainability assessment methodologies. Ecological Indicators, 9, 189-212. https://doi.org/10.1016/j.ecolind.2008.05.011

Sirgy, M. J. (2011). Theoretical Perspectives Guiding QOL Indicator Projects. Social Indicators Research, 103, 1- 
22. https://doi.org/10.1007/s11205-010-9692-6

Smith, A., Snapp, S., Chikowo, R., Thorne, P., Bekunda, M., \& Glover, J. (2017). Measuring sustainable intensification in smallholder agroecosystems: A review. Global Food Security, 12, 127-138. https://doi.org/10.1016/j.gfs.2016.11.002

Stiglitz, E. J., Sen, A., \& Fitoussi, P. J. (2009). Report by the Commission on the Measurement of Economic Performance and Social Progress. Retrieved June 14, 2020 from http://ec.europa.eu/eurostat/documents/118025/118123/Fitoussi+Commission+report.

Strezov, V., Evans, A., \& Evans, T. J. (2017). Assessment of the Economic, Social and Environmental Dimensions of the Indicators for Sustainable Development. Sustainable Development, 25, 242-253. https://doi.org/10.1002/sd.1649

Sureeyatanapas, P., Yang, B. J., \& Bamford, D. (2015). The sweet spot in sustainability: a framework for corporate assessment in sugar manufacturing. Production, Planning \& Control, 26(13), 1128-1144. https://doi.org/10.1080/09537287.2015.1015470

Talukder, B., Hipel, K. W., \& van Loon, G. W. (2017). Developing Composite Indicators for Agricultural Sustainability Assessment: Effect of Normalization and Aggregation Techniques. Resource, 6, 66. https://doi.org/10.3390/resources6040066

Touzard, J. M., Chiffoleau, Y., \& Maffezzoli, C. (2016). What Is Local or Global about Wine? An Attempt to Objectivize a Social Construction. Sustainability, 8, 417. https://doi.org/10.3390/su8050417

United Nations Economic Commission for Europe (UNECE). (2008). Measuring Sustainable Development. Retrieved June 12, 2020 from https://www.oecd.org/greengrowth/41414440.pdf

Villamagna, A., \& Giesecke, C. (2014). Adapting Human Well-being Frameworks for Ecosystem Service Assessments across Diverse Landscapes. Ecology and Society, 19(1), 11. https://doi.org/10.5751/ES-06173190111

Wang, E., Kang, N., \& Yu, Y. (2018). Valuing Urban Landscape Using Subjective Well-Being Data: Empirical Evidence from Dalian, China. Sustainability, 10(36). https://doi.org/10.3390/su10010036

Wei, J., Zhao, Y., Xu, H., \& Yu, H. (2007). A Framework for Selecting Indicators to Assess the Sustainable Development of the Natural Heritage Site. Journal of Mountain Science, 4(4), 321-330. https://doi.org/10.1007/s11629-007-0321-z

Wilson, D. C., Rodic, L., Cowing, M. J., Veils, C. A., Whiteman, A. D., Scheinberg, A., Vilches, R., Masterson, D., Stret, J., \& Oelz, B. (2014). Wasteaware' Benchmark Indicators for Integrated Sustainable Waste Management in Cities. Waste Management, 35, 329-342. https://doi.org/10.1016/j.wasman.2014.10.006

Yang, Q., Ding, Y., de Vries, B., Han, Q., \& Ma, H. (2014). Assessing Regional Sustainability Using a Model of Coordinated Development Index: A Case Study of Mainland China. Sustainability, 6, 9282-9304. https://doi.org/10.3390/su6129282

Zhen, L., \& Routray, J. K. (2003). Operational Indicators for Measuring Agricultural Sustainability in Developing Countries. Environmental Management, 32(1), 34-46. https://doi.org/10.1007/s00267-003-2881-1

Zorondo-Rodrígues, F., Gómez-Baggethun, E., Demps, K., Ariza-Montobbio, P., García, C., \& Reyes-García, V. (2014). What Defines Quality of Life? The Gap Between Public Policies and Locally Defined Indicators Among Residents of Kodagu, Karnataka (India). Social Indicators Research, 115, 441-456. https://doi.org/10.1007/s11205-012-9993-z

Zorrilla-Miras, P., Mahamaneb, M., Metzgera, M. J., Baumertb, S., Vollmera, F., Luzd, A. C., ... Grundye, I. M. (2018). Environmental Conservation and Social Benefits of Charcoal Production in Mozambique. Ecological Economics, 144, 100-111. https://doi.org/10.1016/j.ecolecon.2017.07.028

\section{Copyrights}

Copyright for this article is retained by the author(s), with first publication rights granted to the journal.

This is an open-access article distributed under the terms and conditions of the Creative Commons Attribution license (http://creativecommons.org/licenses/by/4.0/). 